\title{
Žan Kačiga
}

Koledž u Brokportu, Državni univerzitet u Njujorku

\section{Velika strategija Kine}

\begin{abstract}
Sažetak
Kineski predsednik Si Đinping je 2013. godine izneo ciljeve Kine da do 2050. godine dostigne tehnološke, vojne i ekonomske kapacitete bez premca. Obim i razmere aktivnosti koje su preduzete da bi se ti ciljevi ostvarili ukazuju na postojanje velike strategije. Ovaj rad se bavi velikim strategijama u međunarodnim odnosima, primenjujući ideju velike strategije na delatnosti koje Kina preduzima radi ostvarivanja svojih spoljnopolitičkih ciljeva. Neizostavni elementi velikih strategija čine zanimanje za ovu temu opravdanim. Svrha je jedan od tih elemenata. Svrha pomaže da se odgovori na pitanje zarad čega Kina želi da ostvari svoje ciljeve. Ukoliko shvatimo svrhu velike strategije Kine, istovremeno ćemo shvatiti i kako će biti usmeren njen uticaj u slučaju da postigne svoje ciljeve i postane prva država sveta. Ovaj rad stoga ispituje da li Kina ima veliku strategiju i, ako ima, koja je svrha te strategije i kako će ta svrha uticati na međunarodni poredak, odnosno međunarodne odnose.
\end{abstract}

Ključne reči:

velika strategija Kine, spoljna politika, državništvo, dinamika promene

\section{UVOD}

Prepoznavanje i formulisanje nacionalnih interesa neizostavan je deo postojanja države. Uz nacionalne interese, države razvijaju i nacionalne ciljeve koji odražavaju njihove težnje. Zarad ostvarenja najambicioznijih nacionalnih interesa i ciljeva neophodno je posegnuti za državništvom ${ }^{1}$. Za njihovo ostvarenje potrebna je velika strategija. Tema ovog rada su odlike

Državništvo (engl. statecraft) - državnička veština, umeće vođenja državnih poslova, veština rukovođenja državom (prim. prev.). 
velikih strategija. Cilj rada je da dâ detaljan prikaz odlika velikih strategija i da opiše u kojim okolnostima pojedine države osmišljavaju i razvijaju velike strategije. Država na koju ćemo se usredsrediti je Kina. Razlog je naprosto to što je, u kontekstu savremenog globalnog ekonomskog liberalizma, Kina država koja je u skorije vreme - počev od 2013. godine - postavila ambiciozne nacionalne ciljeve. Rad na ostvarivanju i izvršavanju tih ciljeva kroz razne spoljnopolitičke aktivnosti i delatnosti ukazuje na to da oni počivaju na nekoj velikoj strategiji. Stoga ovaj rad ima za cilj i da najpre razjasni da li Kina zaista ima veliku strategiju i, zatim, ako ona postoji, da utvrdi koja je strategija u pitanju. Naposletku, pošto velike strategije podrazumevaju nameru i svrhu, poslednje pitanje bitno za ovaj rad jeste kako će se ta namera i svrha Kine odraziti na strukturu međunarodnog sistema, međunarodnih odnosa i međunarodnog poretka. Poslednje pitanje je važno zbog veličine i potencijala Kine. Ukoliko uspešno ostvari svoju veliku strategiju, Kina će biti u prilici da stekne obilje sposobnosti, zbog čega je zanimanje za nameru i svrhu njene velike strategije bitno za međunarodne odnose.

\section{VELIKA STRATEGIJA}

Pojam velike strategije koriste i istoričari međunarodnih odnosa i politikolozi. U oba slučaja, preuzeli su ga od vojnih istoričara i stratega. Promenivši značenje od prvobitno vojne upotrebe, gde podrazumeva pokušaje da se osigura pobeda u vojnom poduhvatu, ovaj pojam se vremenom proširio i na oblasti koje se ne tiču vojske. Među ličnostima koje su doprinele da dođe do razvoja shvatanja da se pitanja rata ne tiču samo agresije na bojnom polju je i Prus Fon Klauzevic. U delu $O$ ratu on je napravio pomak tako što je poimanje rata proširio izvan poprišta bitaka u širu oblast politika i nacionalnih ciljeva. Po njemu, ratovi podrazumevaju više od potpunog poraza neprijateljskih snaga. Premda je bio odlučan vojskovođa, koji jeste tvrdio da "direktno uništenje neprijateljskih snaga uvek mora biti primarno" (Clausewitz, 2010: 228), Fon Klauzevic je bio mislilac i stoga je prepoznao da pitanja rata niti počinju niti se završavaju na bojnom polju. Ona počinju i završavaju se s nacionalnim ciljevima. Nacionalni ciljevi su, međutim, primarni za državništvo, a ne samo za generale. Stoga i vojni poduhvati i ratovi vođeni s ciljem da se postignu nacionalni ciljevi predstavljaju instrumente državništva. Vojna strategija je samo deo veće strategije koju država može da koristi zarad postizanja nacionalnih ciljeva. A kada takva strategija uključuje i podršku, korišćenje, aktiviranje i doprinos drugih državničkih instrumenata onda je reč o velikoj strategiji. 
Etimološko poreklo reči strategija iz starogrčkog jezika ukazuje na naredbu generala i, štojejoš važnije, pretpostavku i očekivanje da je svaka takva naredba valjano osmišljena. Lidel Hart definiše strategiju kao „praktično prilagođavanje sredstava koje general ima na raspolaganju zarad ostvarenja cilja koji ima pred sobom" (Hart, 1967: 334). Strategija podrazumeva razmišljanje. Uostalom, cena posledica neadekvatne i nedovoljno osmišljene naredbe koju izda general u ratu je, po prirodi stvari, velika u svakom smislu te reči. Strategije stoga označavaju proizvod razmišljanja, rezultat plodnog rezonovanja. One podrazumevaju kalkulisanje koje uzima u obzir sve poznate činioce i ima rezervu prema nepoznatom. One predviđaju otpor i iznenađenja i moraju u potpunosti da iskoriste sve prilike i sredstva. One razmatraju kako resurse i ljude najbolje iskoristiti, koriste vreme i prostor i prirodno daju plan za odgovarajuće izvršenje, nadajući se željenom ishodu. Upotreba ovog izraza uvek podrazumeva takav proces. Kada se on spoji s pridevom velika uključuju se i svi drugi činioci koji direktno ili posredno doprinose postizanju željenog ishoda. Hartov pojam „posrednog prilaženja” odnosi se na korišćenje instrumenata državništva protiv svih neprijatelja i na bilo koji način da bi se prevagnulo u sopstvenu korist. S obzirom na mogućnosti koje pruža tehnologija, danas pojam „posrednog prilaženja” može da se primeni i na oblasti i mesta događanja koja Hart nije predvideo. Ipak, pobeda na bojnom polju nije dovoljna. Velika strategija treba da garantuje dugoročan efekat pobeda. Ona treba da teži postizanju mira. To gledište može da se primeni na slučaj Sjedinjenih Američkih Država (SAD); one su imale veliku strategiju da pobede u II svetskom ratu, ali su se takođe postarale da se kroz liberalni poredak posleratnog liberalnog institucionalizma postigne mir. $\mathrm{Na}$ taj način usvajanje pristupa velike strategije prevazilazi neposredne aktivnosti vođenja rata. Ona obezbeđuje da uspeh postignut s dostizanjem nacionalnih ciljeva ne bude kratkotrajan.

Zbog svega toga, velika strategija je sveobuhvatan pristup. Van Hoft definiše veliku strategiju naprosto kao strategiju koja „određuje kako države, i drugi politički entiteti, određuju prioritete u upotrebi vojnih, diplomatskih, političkih, ekonomskih i drugih izvora moći i na koji način ih koriste da bi osigurali ostvarenje onoga što opažaju kao svoje interese" (van Hooft, 2017). Ona koristi instrumente moći poput formalne i javne diplomatije, spoljne politike, ekonomskih i finansijskih podsticaja, resurse datih zemalja, političku volju, pridobijanja podrške naroda, određeni narativ itd. Takvi napori moraju da se koordinišu. Ukoliko je za to koordinisanje neophodno upotrebiti razne državne resurse zarad ostvarenja nekog nacionalnog cilja, onda je taj proces opravdano opisati kao veliku strategiju (Corbett 1988). Takva strategija je onda velika, odnosno ona je „veći” cilj koji treba razlikovati od „manjih" ciljeva, koji su predmet spoljne politike. 
Ovaj pojam se najrazličitije tumači u odnosu na to ko ga upotrebljava. Zbog toga on može da poprimi različite nijanse značenja i mogu da budu naglašeni njegovi različiti aspekti. Neki autori naglašavaju ideju da velika strategija podrazumeva samo velike planove, velika načela i velike aktivnosti, u čijoj primeni mogu da se uoče obrasci (Silove 2018), a drugi, poput Lutvaka, tvrde da velika strategija ne mora da postoji u pisanom obliku, posežući za primerom Vizantijskog carstva (Luttwak, 2009). Štaviše, Lutvak smatra da države uvek imaju velike strategije, bilo da su toga svesne ili nisu. Postojanje velike strategije i njeno logično izvršavanje nisu uvek praćeni svešću o njoj. Međutim, taj nedostatak svesti može postati problem ako ometa sposobnost države da osmisli propratni narativ za izvršenje velike strategije. Diplomate mogu da na smislen način pokušavaju da ostvare neki spoljnopolitički cilj bez iznalaženja nekog bitnijeg razloga za to što rade. Ipak, poznavanje svrhe spoljnopolitičkog cilja svakako doprinosi stepenu posvećenosti datom cilju. Na primer, za američke diplomate je sprovođenje neke politike tokom Hladnog rata poprimalo novu dimenziju zbog toga što su oni znali da je data politika usmerena ne samo protiv Sovjetskog Save$\mathrm{za}$, već i protiv komunizma. S tačke gledišta SAD, narativ je bio borba protiv komunizma za slobodan svet. To je ono što opravdava narative velikih strategija. Ipak, možda ni narativ nije važan. Drezner tvrdi upravo to - da je važnost tog pojma precenjena (Drezner, 2011). Lutvak insistira na tome da je važno samo da se strategija sprovodi strukturisano i neprekidno. On ukazuje na to da je Vizantijsko carstvo koristilo sredstva poput diplomatije, finansijskih podsticaja, država-klijenata, obaveštajnih aktivnosti i sile da bi vladalo mnogo duže nego Zapadno rimsko carstvo. Grej veliku strategiju smatra sponom između sredstava i cilja (Gray, 2010). Džon Luis Gadis ${ }^{2}$ koristi više komplementarnih definicija; jedna od njegovih poetičnijih definicija glasi da je velika strategija strategija „kod koje se od šume ne vidi drvo" (Gaddis, 2009). U skorije vreme, Gadis je, baš kao i Grej, definisao veliku strategiju kao sposobnost da se potencijalno neizmerne težnje pomire s kapacitetima koji su nužno ograničeni (Gaddis, 2018). Kada se takve težnje ne poklapaju s praktičnim materijalnim ograničenjima, rezultat je neravnoteža, na koju pažnju skreće Pol Kenedi (Kennedy, 1990). Kenedi razmatra kako sile u povoju primenjuju veliku strategiju u praksi, postižući ambiciozne ciljeve, ali gubeći iz vida da su njihovi ekonomski kapaciteti, koji su neophodni da se ti napori održe, ograničeni. On smatra da se ovaj obrazac ponavlja i stoga njihov neuspeh pripisuje preteranoj gordosti. Jasno, Kenedijeva analiza našla je odjeka u debati koja je usledila u SAD nakon što je

Plenarno obraćanje na skupu The International Security in a New Crisis. UC Channel, jun 2009. 
shvaćeno da njihova privreda više nije mogla da podupre ambiciozne ciljeve neokonzervativnih ideologa $u$ administraciji Džordža Buša. S druge strane, Strahan žali što mnogi taj pojam koriste da bi označili bilo koji spoljnopolitički cilj, zbog čega je teško definisati ga i zbog čega se čak u velikoj meri razvodnjava njegovo pravo značenje (Strachan, 2005). To žaljenje je opravdano naprosto zbog toga što su velike strategije veće od spoljne politike. Velike strategije nisu samo slogani ili tačke na dnevnom redu, niti su naprosto instrumenti konkretnih ciljeva. One treba da budu smele. Treba da budu vizionarske. One su predviđanja o budućnosti. One treba da definišu ideale, a zatim i svrhu; u suprotnom su samo spoljnopolitički ciljevi, ne i velike strategije.

Bilo kako bilo, ukoliko se velike strategije tiču ambicioznih nacionalnih ciljeva, ti ciljevi ne moraju nužno da podrazumevaju vojni sukob, niti da putem takvog sukoba ostvaruju. Velike strategije u potpunosti izmeštaju pojam strategije iz vojne sfere, naprosto zato što cilj koji se u tom slučaju ima na umu nije pobeda na bojnom polju. Nacionalni interesi i ciljevi država nisu primarno niti isključivo vojni. Bitke savremenog doba odvijaju se na različitim poprištima, i materijalnim i nematerijalnim. Nematerijalna bojna polja, poput interneta, nikako ne podrazumevaju vojne zapovednike, već donosioce politika i druge vrste aktera. Poveravanje velike strategije državničkim umećima počiva na sposobnosti donosilaca politika i političkih čelnika da imaju veći učinak od vojnih zapovednika. Time se isključuju vojni poduhvati. Pozitivan ishod toga je da se izbegavaju pobede na bojnom polju koje za rezultat nemaju dugotrajan mir i besmislene pobede, poput Napoleonove pobede u Rusiji. Čak i kad se razdvoje sfera politike i vojna sfera teško je izbeći analogije između bojnog polja i državništva i između komandanata i političkog vrha. I bojno polje i državništvo su oblasti delovanja, a vojni zapovednici i političari moraju da na osnovu svojih sposobnosti najbolje iskoriste resurse koji su im na raspolaganju da bi postigli željeni ishod. Moraju da pokažu sposobnost da koriste i taktiku i strategiju, što nas dovodi do Arhiloha ( 7 vek p. n. e) i njegove metafore o ježevima i lisicama o kojoj piše Isaija Berlin (Berlin 1953), a u skorije vreme u ovom kontekstu i Gadis (Gaddis 2018). Velika strategija zahteva i taktičko i strateško umeće.

\section{DA LI KINA IMA VELIKU STRATEGIJU?}

Elementi velike strategije i aktivnosti koje se sprovode u okviru te strategije mogu, ali ne moraju, da se javno iznesu, iskažu i obelodane. To da li će strategija ili neki njen deo biti predstavljeni svetu ili ne, koliko od strategije će biti otkriveno i kada će se to desiti zavisi od prirode same strategije. Za neke 
strategije je potrebno da aktivnosti budu tajne i diskretne, a neke se namerno obelodanjuju. Naravno, u nekim oblastima potrebno je više diskrecije pri obelodanjivanju strategije nego u drugim. U određenoj meri, svaka strana koja učestvuje u procesu primene vojne, diplomatske, političke, poslovne, finansijske i bilo koje druge strategije zarad nekog konkretnog ishoda ima na umu kakve su joj karte podeljene i kako će odigrati partiju. Stoga otvorenost u obelodanjivanju strategija varira. Ta otvorenost zavisi od ciljeva date strategije. Benigni, bezopasni i legitimni ciljevi ne moraju da se kriju, ali oni čije ostvarenje ide na uštrb neke strane ili drugog aktera zahtevaju diskreciju. U svakom slučaju, odluka da li će se strategija obelodaniti ili ne mora da se donese u zavisnosti od toga kakve posledice ima po saveznike i neprijatelje, ali i potencijalne saveznike i neprijatelje. Ono što se obelodani ne bi trebalo da otuđi saveznike i stvori od njih neprijatelje. Saveznike u najmanju ruku treba uveriti u svoje dobre namere. Ono što se iznese $u$ javnost takođe ne sme ni da alarmira neprijatelja i skrene mu pažnju, jer on treba da bude usredsređen na druge stvari i da ne bude svestan šta se događa. Time se može objasniti postojanje tajnih oružanih sistema. To se posebno odnosi na oružane sisteme, koji u zavisnosti od strategije mogu da budu obelodanjeni ili da ostanu skriveni. Kina, kojom se bavimo u ovom radu, možda i sama ima tajne oružane sisteme, koje su Vork i Grand nazvali „pritajenim kapacitetima” (engl. black capabilities) ili „buzdovanom ubice" (engl. assassin's mace) (Work and Grand, 2019). Takav je slučaj ukoliko strategija ne nalaže suprotno. To je u stvari suština odvraćanja. Potencijalni neprijatelji mogu se odvratiti samo ukoliko su svesni nečijih sposobnosti. Strategija takođe može da nalaže i podsticanje dvosmislenosti i neodređenosti. To se dešava kada neki akter namerno odluči da od potencijalnih neprijatelja krije svoje kapacitete, nadajući se da će time poremetiti njegovu izradu strategije. Takav je, po svemu sudeći, stav koji je zauzeo Izrael u pogledu svojih nuklearnih kapaciteta. U pozadini strategije i ciljeva je namera. Otkrivanje strategije zavisi od namere koja motiviše ciljeve. Prava namera u pozadini nekog cilja može biti prikrivena. Na primer, zašto bi Kina potencijalnim „žrtvama” otkrila da želi da dođe u posed neke tehnologije da bi mogla da se s njima nadmeće, da ih nadigra i uspostavi dominaciju nad njima o kojoj god oblasti da je reč? Jedan primer takve situacije je zabrinutost Zapada u vezi s pokušajima Kine da dođe u posed važne tehnologije $u$ oblasti veštačke inteligencije, mikročipova, mrežnih uređaja za elektronsku komunikaciju, inovacija u izradi procesora, informaciono-komunikacionih tehnologija, vozila na daljinsko upravljanje, računarstva u oblaku (engl. cloudcomputing) itd. Zapad brine na koji način će Kina da koristi tu tehnologiju. Tako su maja 2019. godine SAD po izvršnoj uredbi predsednika zaustavile saradnju američkih telekomunikacionih operatera s kineskom firmom 
Huavej (Huawei) zbog sumnji da Kina ima zadnje namere. Isto tako, zašto bi Kina otkrila pravi razlog za istraživačke misije na tamnoj strani Meseca ako je taj razlog helijum 3, mineral koji ima ogroman energetski potencijal i koji verovatno može da zameni radioaktivni uranijum u razvoju nuklearne energije, pa čak i nuklearnog oružja? Možda Kina nema prikrivenu nameru u istraživanju tamne strane Meseca. Možda je u pitanju samo bezazlena potreba Kine da uspešno ovlada tehnologijama da bi mogla da zauzme svoje mesto među velikim silama i da bi stekla samopouzdanje. Možda je zaista u pitanju to da Kina želi da dođe u posed helijuma 3, baš kao što ulaže izuzetne napore da dobije pristup i ostalim strateškim sirovinama. U oba slučaja, Kina bi skrenula pažnju na svoje postupke i namere i izazvala reakcije i protivmere. Kada bi Kina otkrila svoje namere, to bi onda bio strateški izbor. $\mathrm{Da}$, za strategije je prirodno da podrazumevaju kalkulisanje i iznenađenja, tajnovitost, pa čak i obmanu.

Pokušaji da se uoči velika strategija mogu istovremeno biti i jednostavni i komplikovani. Jednostavni su kada sve u vezi s njom otkriju zakonodavci, bele knjige i zvaničnici, a komplikovani kada ona uključuje obmanjivanje i manevre, iz razloga koje smo već naveli. Ono što je važno je da li u spoljnopolitičkim aktivnostima date zemlje postoje uočljivi, razrađeni i sveobuhvatni obrasci, koji ukazuju na sistematski pristup i imaju jasno usmerenje (ciljeve). Velike strategije, onako kako smo ih ovde definisali, mogu da se uoče na osnovu toga kako se sprovode, čak i kada su prvobitno prikrivene. Zbog toga je potrebno da se posmatraju postupci aktera i istovremeno pažljivo motri na znake postojanja strategije. Ono što primetimo važnije je od onoga što čujemo. Činjenice, postupci i pojave odnose prevagu nad rečima, pa čak i razumom. Uostalom, da parafraziramo filozofa Hegela (Hegel, 1807), nauka počiva na pokušajima da se objasni ono što jeste, a ne ono što se misli. To je, u neku ruku, ono što je Grej imao na umu kada je ustvrdio da čak i nije važno da li je država koja sprovodi veliku strategiju sama svesna te strategije (Gray, 2010). Dovoljno je da se velika strategija može razlučiti u njenim postupcima. Drugim rečima, da bismo znali da li Kina ima veliku strategiju dovoljno je posmatrati kako ona sprovodi svoju spoljnu politiku. U prilog tome treba primetiti da se velike strategije ne osmišljavaju uvek odjednom i u celosti. Velika strategija može da nastane postepeno i s vremenom, kao kad se, ciglu po ciglu, gradi kuća. Važno je samo da ta građevina na kraju liči na kuću, a iz procesa izgradnje mora da se vidi da se cigle ređaju sistematično i da je raspored soba takav da se one međusobno dopunjuju. Odnosno, taj proces mora da bude smislen i da se odlikuje funkcionalnošću. Kina je svakako primer toga. Kineska spoljna politika i nacionalni ciljevi su se promenili od 1978. godine, a Kina je počela da sistematično radi na 
ispunjavanju tih ciljeva tek nakon što je u XXI veku, od kada je Si Đinping na vlasti, stekla sredstva potrebna za ostvarivanje svojih ambicija.

Imajući to na umu, putem dedukcije ćemo trasirati poteze Kine da bismo utvrdili da li oni imaju strateškog smisla. Džang je već odgovorio na ovo pitanje kada je rekao da Kina nema nikakvu kohezivnu veliku strategiju (Zhang, 2012). On, međutim, jeste primetio začetak spoja ideja i interesa kod kreatora kineske spoljne politike. Džangova zapažanja odnose se na njegove utiske o Kini do 2012. godine. Kina je poznata po tome što u roku od jedne decenije ume da napravi veliki pomak. Uskoro će se navršiti decenija od kada je Džang izneo svoja zapažanja, što znači da je Kina od tada najverovatnije dodatno napredovala. Samo godinu dana nakon toga, Komunistička partija Kine izabrala je Si Đinpinga za predsednika. Od tada je došlo do potpunog preobražaja kineske spoljne politike, što ćemo opisati u nastavku rada. Međutim, Džang je i tada primetio da kineska spoljna politika počinje da se menja i, premda u tom trenutku nije uviđao kohezivnu veliku strategiju, predvideo je da će se to možda promeniti. S druge strane, u članku za časopis National Review, Hanson tvrdi da „Kina u stvari nema jednu strategiju kako da pretoči ekonomski uspon u globalnu hegemoniju, već je pre reč o više strategija" (Hanson, 2019).

Iako Džang 2012. godine nije mogao da uoči kohezivnu veliku strategiju, Hanson je 2019. zapazio sprovođenje višestrukih strategija. Pitanje koje se sada nameće je da li možemo da uočimo elemente velike strategije u načinu na koji Kina danas sprovodi spoljnopolitičke aktivnosti i tako potvrdimo da su se stvari zaista promenile od doba kad je Džang izneo svoju konstataciju i da li možemo da se ne složimo s Hansonom ukoliko zaista pronađemo veliku strategiju, a ne nekoliko strategija. Da li možemo da uočimo ciljeve, interese i ishode koje Kina pokušava da dosegne da bi svoj ekonomski uspon pretočila u status svetskog hegemona? Da li su uzete u obzir dimenzije vremena i prostora, pa čak i celokupna sfera međunarodne politike? Da li su razmere i zahvat aktivnosti na sprovođenju tog cilja i nacionalnog interesa dovoljni da je za njih poželjno i neophodno koristiti državne instrumente moći i resurse? Da li Kina ima idejni plan u okviru kog su napori ka ostvarenju njenih ciljeva svrsishodni čak i kada se izuzmu njihovi materijalni aspekti? 


\section{CILJEVI NA KOJIMA POČIVA VELIKA STRATEGIJA KINE}

Ciljevi Kine su se drastično promenili u proteklih nekoliko decenija. Do 1978. godine, Kina je kao druga najvažnija komunistička država bila usredsređena na međunarodno angažovanje na podršci i pomoći zemljama u razvoju da se odupru imperijalizmu i kapitalizmu. Njena spoljna politika tada je bila posvećena promovisanju međunarodnog socijalizma. Nakon sprovođenja ekonomskih reformi 1978. godine i potonjeg uspeha, kineska spoljna politika iznedrila je ciljeve koji održavaju njene nove kapitalističke ekonomske potrebe. S rastom kineske ekonomije povećale su se i razmere i zahvat tog novog cilja. Skromni ciljevi nastali tokom osamdesetih godina prošlog veka kao deo stremljenja ka sirovinama, ekonomskoj pomoći i pristupu tržištima u XXI veku dobili su na zamahu i zahvatu. Nakon 2010. godine, kada počinje doba Si Đinpinga, oni su postali silovitiji, višedimenzionalniji, prodorniji i sveprisutniji, srazmerno ekonomskom napretku. Si Đinping je 2013. godine označio kraj pritajenosti i početak novog doba „stremljenja ka postignućima”. On želi da u potpunosti mehanizuje kinesku vojsku. Želi da Kina postane vodeća zemlja po izvozu gotovih proizvoda. Nakon toga, ima za cilj da za proslavu stote godišnjice dolaska komunističke partije na vlast Kina dostigne izuzetnost.

\section{VREMENSKI OKVIR VELIKE STRATEGIJE}

Cijevi koje je predstavio Si Đinping 2013. godine imali su konkretne ishode i vremenski okvir, što je još jedan važan element velikih strategija. Vojska bi trebalo da bude potpuno mehanizovana do 2020. godine. Kina bi trebalo da postane vodeći izvoznik gotovih proizvoda do 2025. godine. Ostvarenje izuzetnosti bi trebalo da se dogodi do 2049. godine. Do 2050. godine Kina bi trebalo da postane prva zemlja sveta.

Iako je vreme suštinski nematerijalno, ono je za ljude višestruko ograničen resurs. Naše težnje ograničene su vremenski i vremenom. Naši ciljevi se stoga izvršavaju unutar nekog vremenskog okvira. Dalje, ono što možemo da postignemo unutar nekog vremenskog okvira je ograničeno zato što postoje mnogi dodatni činioci i prepreke. Napokon, s ostvarivanjem cilja može i da se zakasni. Može da se promaši vreme u okviru koga bi ostvarenje nekog cilja imalo najveći uticaj. Na primer, neke zemlje su postigle cilj posedovanja nuklearnog oružja. One koje nisu uspele da postignu taj cilj sada kao posledicu trpe uticaj nuklearnog odvraćanja. U međuvremenu, 
posedovanje nuklearnih kapaciteta postalo je neprihvatljivo za međunarodnu zajednicu. One nacije koje nisu postigle taj cilj moraju da funkcionišu bez njegovih strateških pogodnosti. Zbog ograničenosti vremenskog faktora i mnogih potencijalnih empirijskih i političkih smetnji, izuzetno je važno da se postavljeni ciljevi ostvare na vreme. Upravo tu je neophodna strategija. Praktična pitanja, poput finansiranja, osoblja, logistike, stručnosti, studija izvodljivosti, izvršenja zadataka, učinkovitosti i izazova se direktno rešavaju pomoću strategije. Što se Kine tiče, Si Đinping je definisao vremenski tok. Od tada, Kina ima mapu s ucrtanim putem. Ima strategiju. Ta strategija je izvedena iz ciljeva. Za kratkoročne ciljeve potrebna je taktika, ali je za dugoročne neophodna strategija.

\section{RAZMERE I ZAHVAT VELIKE STRATEGIJE}

Da bi postigla ciljeve koje je postavila Kina je stavila u pogon sve instrumente državništva. Kina je sada doslovno u jedinstvenom položaju da može da osmišljava planove srazmerne svojim novostečenim ambicijama. To je položaj dosta velike države, koja ima komparativnu, a nekada i apsolutnu prednost u više oblasti. Ima ostvaren ekonomski rast, na osnovu koga ima pristup finansijama potrebnim da se ostvare njeni ambiciozni ciljevi. Može da kombinuje snage iz javnog i privatnog sektora, jer su u njenom političkom sistemu objedinjeni politički totalitarizam i ekonomski liberalizam. Ta kombinacija omogućava Kini da izbegne nezavisnost i osobenosti privatnog sektora i politički otpor javnog sektora, što su inherentne odlike liberalnih demokratija. Kina stoga može da iskoristi fleksibilnost prvog sektora i moć drugog. To za ishod ima veću sinergiju između finansija i politike, a ta sinergija olakšava osmišljavanje strategije nezapamćenih razmera i zahvata. Ambiciozni ciljevi Kine su globalnih razmera i zahvata. Na ovom mestu u radu bi trebalo da usledi navođenje svih aktivnosti i delatnosti Kine širom sveta. Međutim, to je spisak impresivne dužine, a detalja ima previše za ograničenu nameru rada. Umesto da nabroji sve aktivnosti i delatnosti koje Kina sprovodi, ovaj rad će naprosto navesti oblasti i kategorije kojima one pripadaju, a koje pokazuju razmere i zahvat velike strategije Kine. Ovako izgledaju opseg i zahvat aktivnosti Kine širom sveta.

Pod jedan, Kina istražuje našu planetu (različite kontinente, Arktik i Severni pol) i svemir (tamnu stranu Meseca) u potrazi za strateškim sirovinama, između ostalog i mineralima. Ako dobije pristup ovim sirovinama Kina će moći da obezbedi da postane vodeća nacija i najveća ekonomija sveta. 
Pod dva, Kina želi da svetsku trgovinu usmeri ka Pekingu. Kina je, kako smo ranije naveli, već sada najveći trgovinski partner sedamdeset jedne države i radi na tome da se taj broj poveća. Aktivnosti koje sprovodi u tom pravcu su: intenzivno ulaganje $u$ direktne strane investicije i izgradnju infrastrukture. Te aktivnosti su komplementarne i zato su tako važne za veliku strategiju Kine.

Pod tri, Kina ulaže da bi povećala svoju ulogu u svetskoj trgovini. Njene direktne strane investicije velikim delom su usmerene ka zemljama s visokim nivoima zarada, posebno ka Severnoj Americi i Evropi, u koje se, između 2005. i 2017. godine, ulilo 65,6\% kineskih ulaganja. ${ }^{3}$ Pošto od polovine 2005. godine poseduje velike količine likvidnih sredstava, Kina od tada pokušava da kupi aktivu širom sveta. Direktne investicije kineskih kompanija u inostranstvo, koje su činile samo 4\% celokupnih globalnih stranih investicija, od 2009. godine su prešle 10\%, a u 2016. su dostigle 17\% (McCaffrey, 16. decembar 2017). Po veličini aktive u vlasništvu kineskih kompanija stečene direktnim stranim investicijama, ispred Kine je od 2017. godine samo SAD. Ukupne kineske investicije su se u 2018. godini povećale na 1941,53 milijarde. To se ogleda i u napredovanju kineskih kompanija na Forbsovoj listi 500 vodećih kompanija u svetu. Na toj listi se 2007. godine našlo samo trideset kineskih kompanija, ali se u 2016. taj broj povećao na 109. Direktne strane investicije Kine u Evropi povećale su se s 1.600.000.000 evra (2.000.000.000 dolara) u 2010. godini na 35.000.000.000 evra (44.000.000.000 dolara) u 2016. godini (European Think Tank Network on China). Iz očiglednih razloga, u Evropi su glavne zemlje za investicije bile Nemačka, Francuska, Ujedinjeno Kraljevstvo i Italija. One su središta za proizvodnju tehnologija koje su među najrazvijenijim u Evropi. Kineska ulaganja obuhvataju izgradnju infrastrukture u svim zemljama potpisnicama inicijative „Pojas i put”, pružaoce javnih usluga, saobraćaj, industrijske mašine i opremu i sirovine, koje su Kini potrebne za razvoj proizvodnje. Naravno, zbog takvog razvoja događaja nastala je potreba za diskusijom o kineskoj kupovini vrhunske evropske tehnologije, kao što smo već nagovestili.

Pod četiri, da bi pospešila svoju ulogu u svetskoj trgovini Kina ulaže u izgradnju infrastrukture. Kina gradi kopnene i pomorske puteve, luke, aerodrome i železnice, povezujući kineski Šendžen s Duisburgom u Nemačkoj, Venecijom u Italiji, južnom Azijom, srednjom Azijom, Bliskim istokom, Istočnom Evropom i istočnom obalom Afrike. Ta izgradnja infrastrukture pretočena je u inicijativu „Pojas i put”. Kina je 2017. godine izrazila nameru da proširi inicijativu „Pojas i put” na Latinsku Ameriku. Do danas,

3 Izvor: Heritage Foundation's China Global Investment Tracker. 
Kina je obezbedila prisustvo, pristup, vlasništvo ili zakup kad su u pitanju šest uskih grla međunarodne trgovine: Malajski prolaz, Suecki kanal, Babel Mandeb, Bosfor i Dardaneli, Ormuski moreuz i Panamski kanal. Osim tih tačaka, Kina je osigurala svoje prisustvo i na teritoriji nazvanoj „niska bisera" (engl. String of Pearls), koja obuhvata Sudan, Džibuti, Pakistan, Maldive, Šri Lanku, Bangladeš, Mjanmar, Kambodžu i Hong Kong. Kinesko prisustvo na ovim strateškim tačkama može da se iskoristi i nevezano za trgovinu. Može da se upotrebi za ostvarenje kineskih interesa od Bliskog istoka i Sredozemlja do Indijskog okeana i Južnog kineskog mora. To što se Kina usredsredila na izgradnju infrastrukture omogućilo je kineskim kompanijama da zauzmu sedam od deset mesta na listi najvećih građevinskih kompanija u svetu. Kina gotovo da gradi čitav svet, s obzirom na to koliko je sveprisutna na građevinskim lokacijama širom sveta, a pre svega u zemljama u razvoju. Očigledan razlog za to je to što je zemljama u razvoju neophodna infrastruktura, $u$ šta druge strane zemlje ne ulažu. Kina, međutim, veruje u infrastrukturu i očigledno smatra da bez nje razvoj nije moguć. Regije u kojima su ostvarena velika kineska ulaganja su podsaharska Afrika (119.700.000.000 dolara), Severna Amerika (106.900.000.000 dolara), istočna Azija (98.000.000.000 dolara), zapadna Azija (84.900.000.000 dolara), Evropa (82.500.000.000 dolara), Južna Amerika (77.000.000.000 dolara), arapske zemlje (60.200.000.000 dolara) i Australija (59.200.000.000 dolara). Kina gradi mostove, puteve i železnice na preko dvesta lokacija u svetu, zatim 41 cevovod i 199 elektrana (na nuklearni pogon, gas, ugalj i obnovljive izvore energije). Kina finansira 112 zemalja širom sveta (New York Times, 18. novembar 2018).

Pod pet, od kada je poboljšala ekonomski položaj, Kina se dokazala kao pružalac ekonomske pomoći. Zato je prisustvo Kine u zemljama u razvoju propraćeno zajmovima i bespovratnim sredstvima. Da bi zadovoljila potražnju i u skladu sa svojim statusom pružaoca ekonomske pomoći, Kina je unapredila svoju agenciju za pomoć u razvoju. Marta 2018. godine osnovala je Državnu agenciju za razvojnu saradnju, čija nadležnost je da koordiniše sve veći budžet za inostranu pomoć. To je „institucija koja ima posebnu misiju da kontroliše i raspodeljuje sredstva za međunarodne programe pomoći”, piše Legarda (Legarda, 2018). Najvažnije i najpriznatije velesile imaju agencije za razvojnu saradnju. One su način da se iskaže status bogate, uspele države. To je takođe i način da se uspostave odnosi s mnoštvom država koje tu pomoć primaju i od nje zavise. To je i način da se promovišu kineske grane industrije i da se olakša da se one ustale u ovim državama da bi mogle da ostvare pristup njihovim resursima. Konačno, to je način da se strukturno obezbedi određeni odnos moći između davaoca i primaoca. U tom odnosu, kako kaže jedna izreka, ruka koja daje je iznad ruke koja prima. 
To znači da, gledano kroz prizmu realpolitike, države koje su pružaoci pomoći ne prezaju da iskoriste položaj u ovom odnosu da bi izdejstvovale brojne ishode koji njima idu u prilog ukoliko moraju da rešavaju neko pitanje vezano za državu-primaoca.

Pod šest, Kina ne krije svoj cilj da bude takmac i na kraju izbije na čelo trke u oblasti telekomunikacione infrastrukture i digitalne tehnologije. Nakon što ostvari dominaciju u vidljivom svetu, cilj Kine je da ostvari dominaciju u digitalnom svetu i na polju digitalne bezbednosti. Kina teži apsolutnoj premoći u oblasti informacione tehnologije, vozila na daljinsko upravljanje, veštačke inteligencije i ratovanja putem uništenja neprijateljskih operacionih sistema (engl. systems destruction warfare) ${ }^{4}$. Da bi to ostvarila, Kina želi da ojača sopstvenu mrežu prikupljajući podatke sa svojih servera, pametnih telefona i drugih tehnologija. Čineći sve to, ona pokušava da ostvari kontrolu nad pristupom što većoj količini podataka prikupljenih širom sveta. Posledica toga je kupovina deonica čitavog niza kompanija koje poseduju visokotehnološki kapacitet, što uključuje sve od robotike, veštačke inteligencije, poluprovodnika, biomedicine i vozila na samoupravljanje, do proširene realnosti, senzora, čipova, aeronautike i astronautike i informacionih tehnologija. Pošto se mnoge takve kompanije nalaze na Zapadu, pošto dobar deo kineske tehnologije može da se preusmeri na podmirivanje potreba vojske i pošto neke od tih kompanija probijaju tehnološke granice, u Evropi i SAD je oglašena uzbuna. Komunistička partija Kine će servisirati i kontrolisati te podatke, zbog čega je ona 2014. godine oformila Upravu za digitalni prostor, koju finansira kineska vlada (Gorrie 2019). Kina želi da bude spremna da se bori u prostoru koji smatra bojnim poljem budućnosti, a to je digitalno bojno polje. Kao što je čelik bio sirovina neophodna za municiju na bojnim poljima u prošlosti, silicijum je sirovina potrebna za tehnološko bojno polje budućnosti. Zbog toga je Dejvid Goldman rekao: „Silicijum je za vojnu moć u XXI veku ono što je čelik bio za vojnu moć u XIX veku" (Goldman, 2019). Digitalno bojno polje je poprište sajber-ratova, koji će sva bojna polja objediniti u jedno. Ekonomske bitke, političke bitke i tehnološke bitke se mogu voditi na digitalnom bojnom polju i preko njega. $\mathrm{Na}$ tom polju je na kocki državna bezbednost. Cilj je imati sposobnost dobijanja bilo koje bitke na tom polju. Gori smatra Kinu jedinom nacijom koja ovaj rat vodi s namerom i strateški (Gorrie, 2019). Kinu je u poslednjih nekoliko godina zbog korišćenja 5G tehnologije za špijuniranje kritikovala Australija. Garnou (Garnaut) je 2018. napisao:

Ratovanje putem uništenja neprijateljskih operacionih sistema ometa ili onesposobljava borbene komandne, komunikacione i obaveštajne sisteme neprijatelja. 
Debata o ovom pitanju u Australiji je prešla put od nedefinisanih zabrinutosti vezanih za uticaj i meku moć Kine do preciznijih briga o tajnom mešanju Komunističke partije Kine. Izveštaji u medijima otkrivaju tajni svet mita, pretnji i uverljivog poricanja. Oni otkrivaju i dimenziju rizika koja postoji između ekonomskog privlačenja, s jedne strane, i vojne sile, s druge, na koje zapadni sinolozi, diplomate i službe bezbednosti ranije nisu obraćali pažnju. Što više saznajemo sve se više čini da je malo toga „mekano” u vezi s tim kako Komunistička partija koristi moć izvan granica svoje države (Garnaut, 2018).

Pod sedam, takva tehnologija je važna za još jednu oblast - vojsku. Kina je otkrila da i u toj oblasti ima cilj da do 2050. godine ostvari apsolutnu premoć. Otpočela je intenzivnu modernizaciju i uvećavanje vojske i može da koristi svoju aeronautičku tehnologiju kako za vojne tako i za civilne potrebe. Prvi kineski tajkonaut (astronaut) lansiran je u svemir 2003. godine, a Kina je uspešno sprovela i test protivsatelitskog oružja. Ona poseduje šezdeset do sedamdeset interkontinentalnih raketa na koje mogu da se postave nuklearne bojne glave i između 240 i 400 bojnih glava (Lanteigne 2016). Od 2016. godine Kina poseduje i nosače vazduhoplova, koji su, kad su vojni kapaciteti u pitanju, najvažniji statusni simbol mornarice za otvoreno more. Postignuća Kine neprekidno se nižu. Najnovije postignuće su radarski nevidljivi mlazni lovci pete generacije J-20 5 s velikim doletom. Kina je razvila rakete vazduh-vazduh PL-15, PL-XX i PL-10, koje su, redosledom kojim su navedene, rakete s najboljim performansama do sada. Ove rakete su opremljene radarom s faznom antenskom rešetkom, koji onemogućava pokretljivim mlaznim lovcima da pobegnu. One mogu da pogode vazduhoplovne sisteme za upozoravanje i kontrolu koji se sporo kreću. Zatim, kineska vojska ima i samovođene rakete. Sve ovo oružje otisnulo je Kinu među vodeće sile u trci u oblasti vazduhoplovstva i ona je sada u rangu SAD. Kina nastavlja da se razvija i sarađuje s drugim zemljama, poput Rusije, da bi razvila ili kupila oružane sisteme kao što je sistem za protivvazduhoplovnu odbranu S-400. Ona drastično povećava svoje vojne kapacitete, što se vidi i iz stalnog porasta budžeta za odbranu. Što se tiče mornarice, koja je iz razloga koji su ranije spomenuti bitan deo kineske vojske, Kina je za četiri godine oformila flotu koja prevazilazi francusku mornaricu. Za četiri godine ona je porinula više ratnih brodova i podmornica, čamaca za podršku i većih desantno-jurišnih brodova od ukupnog broja brodova u floti Velike Britanije (International Institutes for Strategic Studies, London, 2019).

J-20 je dvomotorni nevidljivi lovac s krilnim dodacima za povećanje stabilnosti, naprednom elektronikom i tri unutrašnja odeljka za rakete vazduh-vazduh i bombe. 


\section{DA LI SE NEDVOSMISLENO MOŽE UTVRDITI KOORDINISANOST NAPORA KOJI SE PREDUZIMAJU?}

Strateški potezi su deo strateškog cilja i zato se oni ne odvijaju u izolaciji već u kontekstu odnosa s drugim elementima strategije. Svi oni moraju da budu koordinisani. Iz razloga koje smo ranije izneli, nalaženje dokaza o koordinisanosti raznih aktivnosti Kine u okviru velike strategije je podjednako teško kao pronalaženje bele knjige koja otkriva tu strategiju. Naravno, potraga bi počela pokušajem da se nađe bela knjiga Kine o velikoj strategiji. Kada bi takav dokument i postojao, on ne bi sadržao svaki korak te strategije. Međutim, mogu se pažljivo analizirati razni potezi i delatnosti u spoljnopolitičkim aktivnostima Kine da bi se od tih elemenata sklopila određena slika. Ovaj rad čini i jedno i drugo, ali se više oslanja na spoljnopolitičke aktivnosti. Hijerarhijska politička struktura moći u Kini, njen totalitarni komunistički režim i simbioza između vladajuće komunističke partije i vlade omogućavaju da se formuliše radna hipoteza da se svaka zvanična aktivnost u ime Kine, uključujući i privatni sektor, vrši uz dozvolu državnog vrha. U Kini se svuda mogu pronaći empirijske činjenice koje idu u prilog toj hipotezi, od štampe i medija do kompanija i ulaganja i, naravno, od javne do formalne diplomatije, itd. Pošto ta dozvola nije reaktivna već proaktivna, kineski zvaničnici treba da te korake koordinišu da bi oni bili međusobno usklađeni. Individualnost, nesklad i nedefinisane želje nisu nešto što odlikuje totalitarizam. Organi koji u Kini donose odluke su Stalni komitet Politbiroa (sastoji se od sedam članova i predsedava mu Si Đinping), veliki Politbiro (27 članova), Centralni komitet od 200 članova, Centralni komitet za sveobuhvatne i produbljene reforme, Komitet za nacionalnu bezbednost, partijski Kongres, Ministarstvo spoljnih poslova i druga ministarstva. Si Đinping predsedava ovim organima ili nagleda njihov rad. Ova hijerarhijski organizovana tela sprovode rad Kine na ostvarenju nacionalnih ciljeva. Zbog toga je rad na cilju da Kina postane središte svetske trgovine, neprikosnovena vojna sila, vodeća nacija na polju digitalne tehnologije i na digitalnom bojnom polju budućnosti i da, naposletku, do 2050. godine postane vodeća zemlja sveta komplementaran i koherentan. Svaki element kineskih spoljnopolitičkih aktivnosti može se isplesti u veliku mrežu, čija mustra, oblik, razmere i opseg svi zajednički vode u pravcu postizanja njenih ciljeva.

Iz te domaće hijerarhijski organizovane laboratorije se vrši rad na ostvarenju velike strategije preko ad hok bilateralnog ili multilateralnog institucionalizovanog okvira saradnje s drugim državama. Taj institucionalni okvir postaje vodič za praćenje koherentnosti međunarodnih aktivnosti 
Kine. On otkriva postupke i stav Kine koji ukazuju na to da su rezultat koordinisanog napora. Kina integriše postojeće međunarodne institucije (poput Svetske trgovinske organizacije) ili formira nove međunarodne institucije, koje su instrumentalizovane za ostvarenje nacionalnih ciljeva. To se bolje vidi na primeru institucija koje je formirala nego na primeru institucija koje je integrisala. Kina je oformila pomoćne multilateralne institucije iz domena finansija i bankarstva da bi finansirala zajmove i bespovratna sredstva i njima upravljala. Ona pomaže u finansiranju Nove razvojne banke (od 2014. godine) i Azijske banke za infrastrukturna ulaganja (AIIB), koja je u mnogo čemu kopija Svetske banke i koja ima 57 članica osnivača, među kojima su i zemlje poput Indije, Saudijske Arabije, Filipina, Turske, Australije, Brazila, Francuske, Španije, Ujedinjenog Kraljevstva i Nemačke. Sve te države su tradicionalni partneri SAD koje SAD još nisu ubedile da se ne priključe. Kina svake godine održava samite s grupacijama država u kojima ima sve važniju ulogu. Jedan od najvažnijih samita je Kinesko-afrički forum za saradnju, koji se održava od 2005. godine. Od 2016. godine, Fond Kine i zemalja Srednje i Istočne Evrope, kojim upravlja kompanija Fajnenšal holdings d.o.o (Financial Holdings Ltd. China - CEE), ili 16+1 i u okviru koga je za infrastrukturu, visokotehnološku proizvodnju i potrošnu robu izdvojeno 11.150 milijardi dolara, povezuje Kinu i zemlje Istočne, Srednje i Južne Evrope. Tu su i samiti Zajednice latinoameričkih i karipskih zemalja (CELAC), koji spajaju Kinu s Latinskom Amerikom i karipskim nacijama. Tu je i Forum za saradnju Kine i arapskih zemalja (CASCF), koji se od 2004. sastaje jednom u dve godine. Forum se poslednji put sastao u Kataru u julu 2018. godine. Saradnja Kine i arapskih zemalja obuhvata politička i ekonomska pitanja i pitanja kulture. Interes Kine da sarađuje s Bliskim istokom potiče od geografskih odlika te regije. Pošto se nalazi na sredini kopnenog i pomorskog puta inicijative „Pojas i put”, Bliski istok povezuje Kinu i evroazijski kontinent. Svi ti novi putevi bilateralne i multilateralne saradnje uvećavaju broj postojećih institucionalnih i režimskih mehanizama koje je Kina već uspostavila u Aziji. Inicijativa „Pojas i put” postaje spona koja sve ove zemlje i regije privlači u orbitu Kine i definiše njihovo mesto u toj orbiti.

\section{TELEOLOGIJA VELIKE STRATEGIJE}

Kineski zvaničnici u raznim saopštenjima za javnost često objašnjavaju čime su motivisani ciljevi unutar zemlje i u inostranstvu. Oni tvrde da Kina želi da kroz trgovinu doprinese napretku kineskog naroda i da je ekonomska 
saradnja s drugim državama situacija u kojoj svi dobijaju. Oni, sasvim opravdano, žele da obezbede domovinu tako što će ojačati vojsku, koja treba da postane neprikosnovena, i tako što će biti pobednici na bojnom polju budućnosti, odnosno u digitalnom prostoru, koji obuhvata i ekonomske i vojne bitke. Uopšte uzev, javni diskurs u Kini usmeren je ka tome da se obnove slava i veličina koje je Kina dostigla u prošlosti. To su legitimni motivi za ove ciljeve. Ipak, oni ne izražavaju svrhu. Dva sukcesivna sekretara partije, Hu Đintao i Si Đinping, su u skorije vreme izrazili želju da međunarodna zajednica postane „zajednica koja će imati zajedničku budućnost”, iz čega se potencijalno može izvesti ta teleologija, ali to nije potvrđeno. Ako Kina ima veliku strategiju, da li ta strategija ima svrhu? Da li ona ima idejnu vrednost i težnju mimo potrebe Kine da, u ekonomskom ili vojnom pogledu, bude prva država sveta? Možda Kina želi da bude najnaprednija i najmoćnija i ništa više od toga. Ima osnova za tvrdnju da su to validni ciljevi i motivacioni činioci. Uostalom, oslobađanje od bola pretrpljenog tokom godina poniženja dovoljna je svrha sama po sebi. Ima osnova i za tvrdnju da će, da bi se odbranila od moćnih neprijatelja, poput SAD, Kina morati da bude makar podjednako moćna, što opravdava stremljenja ka vojnoj superiornosti. Kina je još uvek komunistička država. Ona se drži ideala koji se razlikuju od ideala liberalizma, a ideale liberalizma prihvata samo zato što joj donose ekonomsku dobit. Uz to, Kina je tradicionalno konfučijanska zemlja i nedavno je revitalizovala konfučijanski pogled na svet. To znači da Kina kao država ima dva identiteta i da oba ta identiteta mogu da posluže kao osnova za njenu svrhu. Nijedan od ta dva identiteta nije liberalan. To takođe znači da bi Kina mogla da razvije ideju svrhe različitu od one koja se nalazi u osnovi savremenog međunarodnog poretka. Ako je Kina počela da izaziva otpor Zapada zbog naprednih telekomunikacionih tehnologija, razlog za to su razlike u vrednosnim sistemima zasnovanim na identitetu. Svrha je viša težnja zarad koje se postavljaju ciljevi. To pitanje čini teleologiju velike strategije Kine relevantnom.

Lavina aktivnosti Kine na obezbeđivanju prednosti za buduće nadmetanje u digitalnom prostoru daje povoda pitanju - koja je krajnja svrha tih aktivnosti? Ako je ta svrha benigna, nema potrebe za zabrinutošću što će Kina doći u posed helijuma 3 da bi iskoristila njegov ogroman potencijal. Ako je svrha benigna, nema razloga za zabrinutost $u$ vezi s istraživanjem Severnog pola i prisustvom Kine na Arktiku. Ako je ta svrha benigna, nema potrebe ni za zabrinutošću u vezi s potragom Kine za strateškim sirovinama. Ako je ta svrha benigna, ne treba se brinuti ni u vezi s nastojanjima Kine da obezbedi prevlast u Južnom kineskom moru, koje ima bogata priobalna nalazišta nafte. Ako je ta svrha benigna, ne treba biti zabrinut ni $\mathrm{u}$ vezi s novonastalim interesovanjem Kine za vojne baze. Međutim, ukoliko 
je ta svrha usmerena isključivo ka interesima Kine, sve njene trenutne aktivnosti tumačiće se kao koraci koje preduzima jedna sila koja je u usponu, što bi svet približilo slici kakva je opisana u teoriji smenjivanja hegemona. Pošto namera Kine i samim tim i svrha njenih aktivnosti nije poznata, te aktivnosti mogu da izazovu zabrinutost nekih zemalja. Nema jasnog odgovora na pitanje o tome koja je svrha delatnosti Kine. Međutim, to što je taj odgovor nejasan ne znači da ga nema niti da se on ne može jasnije pojmiti u bliskoj budućnosti. Kina se trenutno uveliko bavi sprovođenjem i izvršavanjem onih faza i dimenzija svoje velike strategije koje su već definisane i određene. Kad za to bude vreme, Kina bi mogla da sebi odredi nov i drugačiji put. Ona ima različite izvore suprotstavljenih vrednosti iz kojih se mogu izvesti novi principi i definisati nove norme za potrebe nekog narednog poretka. Jedan takav izvor je konfučijanstvo. Da bi se druge države ubedile, podstakle, pa čak i primorale (a to ima svoju cenu) da se vrednosti zasnovane na konfučijanstvu nametnu u međunarodnom poretku, Kini će biti potrebne materijalne sposobnosti. Za to će biti potrebna ogromna politička volja. Čini se da je Kina svesna te idejne dimenzije, odnosno potrebe da se njena veličina zaokruži u pogled na svet koji nudi vrednosti koje druge države mogu da dele i koje su dovoljno privlačne da bi ih one usvojile. Zarad toga, Kina koristi sredstva meke moći i javne diplomatije tako što osniva konfučijanske institute i kineske medije preko kojih se šire kineske vrednosti i pogled na svet. To što se ovakva upotreba meke moći i javne diplomatije odigrava baš u ovoj fazi njenog ekonomskog uspona govori u prilog tome da je Kina više nego svesna potrebe da njene potencijalne hegemonske pretenzije imaju neku idejnu potporu.

\section{ZAKLJUČAK}

Izneo sam argumente $\mathrm{u}$ prilog tome da Kina ima veliku strategiju i da je sprovodi. Velika strategija se sprovodi tako što se određen broj elemenata aktivno usklađuje u cilju postizanja nekog konkretnog ishoda. Utvrđeno je da kineske spoljnopolitičke aktivnosti sadrže takve elemente. Utvrđeno je da način na koji Kina vodi spoljnu politiku odražava postojanje svih tih elemenata velike strategije izuzev jednog. Kina, naime, tek treba da izrazi i pokaže postojanje neke svrhe. Teleologija te strategije je nedefinisana. Da bi Kina ostvarila svoje ambicije u svetu potrebna joj je stabilna osnova. Potrebna joj je svrha. Kina još uvek može da iznedri tu svrhu, ili možda i nije tako. Snaga posleratnog poretka ne potiče od superiornih sposobnosti Zapada, već pre svega od privlačnosti njegove liberalne svrhe, odnosno svrhe da 
ljudska bića budu suštinski slobodna u pravima i potrazi za srećom. Nakon što se izjednači s materijalnim sposobnostima Zapada ili ih prevaziđe, Kina će, da bi ostvarila svoje ambicije, morati da dostigne ili prevaziđe privlačnost liberalnog poretka. I dalje je potreban odgovor na pitanje: Kina ima veliku strategiju, ali koja je njena svrha? Jedan od odgovora je da Kina možda i nema svrhu. Možda je postizanje postavljenih ciljeva jedino opravdanje za postojanje njene velike strategije, a možda i nije tako.

\section{LITERATURA}

1. Berlin, Isaiah. The Hedgehog and The Fox. An Essay on Tolstoy's View on History. Elephant Paperback. Evan R. Dee Inc. Chicago, 1993.

2. Corbett, Julian. Some Principles of Maritime Strategy. In: Erik J. Grove (Ed.). Classics of Sea Power, Annapolis, MD, Naval Institute, 1988.

3. Drezner, Daniel W. Does Obama Have a Grand Strategy? Why we need Doctrines in Uncertain Times. Foreign Affairs 90-4, 2011, 57-60, 61-68.

4. Gaddis, John, Lewis. On Grand Strategy. Penguin Press, New York, 2018.

5. Garnaut, John. How China Interferes in Australia: And How Democracies can push back in: Foreign Policy, September 3, 2018.

6. Gilpin, Robert. War and Change in World Politics. New York, Cambridge University Press, 1981.

7. Gorrie, James. China's Big Plan to Rule the World. The Epoch Time, March 15, 2019.

8. Gray, Collin. The Grand Strategy Bridge: Theory and Practice. Oxford University Press, 2010.

9. Goldman, David. What is China's Grand Strategy? The Heritage Foundation, May 23, 2019.

10. Hart, Liddell B. H. Strategy. Faber and Faber, England, 1967.

11. Hanson, Victor Davis. China's Brilliant, Insidious Strategy. National Review, May 14, 2019.

12. Hegel, G. W. F. The Phenomenology of the Spirit, 1807.

13. Helena Legarda, China Upgrades Diplomacy While the US Pulls Back. The Diplomat, March 20, 2018.

14. Ignatius, David. China has a Plan to Rule the World. Washington Post, November 28, 2017. 
15. Ikenberry, John, Kupchan, Charles. Liberal Realism: The Foundations of a Democratic Foreign Policy. The National Interest, No. 77, Autumn 2004, pp. 38-49.

16. Kennedy, Paul. The Rise and Fall of Great Powers. Princeton University Press, 1990.

17. Kuegler, Jacek, Organski, A.F.K. The Power Transition: A Retrospective and Prospective Evolution. In: Handbook of War Studies. Ed. Midlarsky, Manus. I, pp. 171-194, Boston, Unwin Hyman 1989.

18. Lague, David, Lim. Kang. China's Vast Fleet is Tipping the Balance in the Pacific. Reuters Investigates The China's Challenge. 2019.

19. Lanteigne, Marc. Chinese Foreign Policy: An Introduction. Routledge, 2016.

20. Legarda, Helena. China Upgrades Diplomacy While the US Pulls Back. The Diplomat, March 20, 2018.

21. Lim Kang, Lague, David. East Asia before the West: Five Centuries of Trade and Tribute. Columbia University Press, 2012.

22. Luttwak, Edward. The Grand Strategy of the Byzantine Empire. Cambridge, MA, Beknap Press of Harvard University Press, 2009.

23. McCaffrey, Courtney Rickert. How Chinese FDI Will Transform the Global Economy. The Diplomat, 16. December 2017.

24. Modelski, George. The Long Cycle of Global Politics and the Nation State. In: Comparative Study in Society and History, Notebook 20, April 2, 1978, pp. 214-235.

25. Modelski, George, and Thompson, R. William. The Long and the Short of Glob al Politics in the Twenty First Century: An Evolutionary Approach. Notebook 1, No. 2, Summer 1999.

26. Organski, A.F.K. World Politics. A. Knopf, 1958.

27. Popper, Karl. Objective Knowledge. An Evolutionary Approach. Oxford University Press, 1972.

28. Silove, Nina. Beyond the Buzzword: The Three Meaning of Grand Strategy. Security Studies 27 (2008).

29. Strachan, Hew. The Lost Meaning of Strategy (2005) Survival 47, 33-54.

30. Soroka, N. Stuart, Wlezien, Christopher. Degrees of Democracy. Cambridge University Press, 2010.

31. Van Hooft, Paul. Grand Strategy. Oxford Bibliographies, 2017; https:// www.oxfordbibliographies.com/view/document/obo-9780199743292/obo9780199743292-0218.xml.

32. Von Clausewitz, Carl. On War. The Floating Press, 2010. 
33. Work O. Robert, Grand, Greg. Beating the Americans at Their Own Game. An Offset Strategy with Chinese Characteristics.Center for a New American Security, June 6, 2019.

34. Xuetang, Yan. From Keeping Low Profile to Striving for Achievement. Chinese Journal of International Politics. 7.2 (2014) 153-184.

35. Zhan, Feng. Chinese Hegemony: Grand Strategy and International Institutions in East Asian History. Stanford University Press, 2015.

Prevod

Jelena Bošnjak 